\title{
QUESTÃO DA VERDADE: UM ESTUDO FILOSÓFICO SOBRE A FAKENEWS
}

\section{Resumo:}

Ana Flávia Costa Eccard ${ }^{1}$ Salesiano Durigon ${ }^{2}$

O atual artigo busca compreender como objetivo geral a investigação de verdade, pósverdade, seu conceito e história com a finalidade de fundamentar estudo sobre a influência do fenômeno das fakenews que acontece das redes sociais, sendo este o objetivo específico. A pós-verdade é um conceito contemporâneo em termos históricos e suscita um entendimento de uma verdade, que é um conceito que atravessa toda a história da filosofia. $\mathrm{O}$ artigo se realiza pela metodologia de pesquisa exploratória pelo método de levantamento de bibliografia.

Palavras-chave: Fakenews; verdade; pós verdade; filosofia; aletheia.

\section{THE QUESTION OF TRUTH: A PHILOSOPHICAL STUDY ON FAKENEWS}

\begin{abstract}
:
The current article seeks to understand as a general objective the investigation of truth, posttruth, its concept and history in order to support a study on the influence of the fakenews phenomenon that happens in social networks, which is the specific objective. Post-truth is a contemporary concept in historical terms and raises an understanding of a truth, which is a concept that runs through the entire history of philosophy. The article is carried out by the exploratory research methodology through the bibliography survey method.
\end{abstract}

Keywords:

Fakenews; truth; post truth; philosophy; aletheia.

\section{INTRODUÇÃO}

A significação da verdade se relaciona com o sentido de fidelidade à realidade, significa pressupor que existe uma qualificação dos valores que deve ser considerada e tida como correta. Outra significação corriqueira se embasa na verdade ser um contraponto da ficção ou do imaginário. A correspondência com os fatos em um encadeamento lógico tem

\footnotetext{
${ }^{1}$ Doutora em Direito pelo PPGD UVA/RJ, doutoranda em Filosofia pelo PPGFIL - UERJ. Advogada. Docente do Mestrado de Direito e Desenvolvimento Unifacvest. Email: anaeccard@ gmail.com.

2 Doutorando em Direito pela Universidade Veiga de Almeida -UVA/RJ. Graduado em Direito pela Universidade do Planalto Catarinense- UNIPLAC (2008). Atualmente advogado, assessor da Federação dos Agricultores Familiares de Santa Catarina - FETRAF-SC, assessor Jurídico do município de Rio do Campo-SC e sócio de capital da Durigon Sociedade de Advogados. Email: advdurigon27373@gmail.com.
} 
uma influência direta em um discurso de autoridade na sociedade logocêntrica ${ }^{3}$ (DERRIDA, A Farmácia de Platão, 2005).

\section{DESENVOLVIMENTO}

Em termos gerais, o conceito de verdade pode ser relacionado em uma dicotomia no que é verdadeiro ou falso, o que pode se entender como uma teoria absoluta, em outros termos podem ser compreendida a partir de uma relativização, a verdade enquanto um instrumento da linguagem. Tais orientações são fortemente debatidas na obra de Platão, quando ele diferencia os filósofos dos sofistas. Nessa perspectiva, há um comprometimento da verdade que é moralizada pelo papel do filósofo, que é claramente defendida na "República". A perspectiva platônica sobre os sofistas propõe uma crítica a qual a verdade se relativa por uma conveniência do discurso, em que a verdade é um instrumento de convencimento e não está relacionada à virtude da alma, mas é uma perspectiva da linguagem (LOPES, 2017).

O chamado intelectualismo socrático tem origem na dicotomia filósofo e sofista a partir da compreensão da verdade que para o primeiro terá uma transcendência com caráter de virtude, e para o segundo estará na ordem de uma técnica de uso da linguagem. A motivação platônica é ética, já a motivação de Protágoras, um sofista, é uma estratégia do diálogo. A construção de conhecimento deve estar ligada à virtude da alma ${ }^{4}$.

O ponto de destaque da compreensão da verdade na antiguidade é observar que se trata de um termo que transcende as questões da realidade e está ligada à uma perspectiva ética. $\mathrm{Na}$ perspectiva platônica, está ligada ao mundo das ideias. Para Platão, a ética está correlacionada à melhor forma de se viver e para isso suas atitudes devem ser conectadas à virtude. Assim, Platão entende a verdade como resultado de uma união entre a moral e o conhecimento, sendo somente alcançada dessa maneira (MARCONDES, 1997).

\footnotetext{
${ }^{3}$ O logocentrismo é um termo utilizado pelo filósofo Jacques Derrida para correlacionar uma teoria da desconstrução. Trata-se de uma crítica a Platão por sua busca constante pela verdade, em um pensamento ocidental que centraliza o logos, transliteração do grego palavra ou razão como fundamento principal do discurso.

${ }^{4}$ Protágoras é um interlocutor de Platão que apresenta a distinção, em seu diálogo, do que seria o filósofo do sofista, distinção tradicional da filosofia ocidental. No diálogo "Protágoras", Platão apresenta a oposição a esse que ele vai chamar de falso filósofo, compreende ainda que o que não tem correspondência com a verdade, não é. Portanto um sofista é um não ser, na compreensão de uma metafísica da verdade. A proposta platônica é que esse indivíduo que utiliza a linguagem para o convencimento não é um sábio.
} 
Esse pensamento antigo ecoa até os dias de hoje na concepção que se tem sobre a verdade. A influência da concepção grega na busca da verdade permeou toda a ciência ocidental e forjou um entendimento de valorização da verdade em detrimento da não verdade. Entretanto, tal concepção fomenta a discussão sobre a existência de uma verdade única e irrefutável, colocando em pauta diferentes noções e percepções da realidade. Conceber a existência de uma verdade soberana e da vida a partir dela esbarra na armadilha de se ter um discurso hegemônico sem espaço para a diferença.

Nesse sentido, o pensamento moderno, que inaugura o racionalismo com René Descartes, compreende que a verdade não se oriunda nem das abstrações nem da alma, significa dizer que a verdade não reside nas ideias inatas. Descartes inaugura a verdade enquanto método, para ele, em seu projeto de legitimar a ciência, sistematizou o conhecimento em certezas inquestionáveis do cogito ergo sum.

A partir da dúvida cartesiana, na elaboração dos argumentos justificativos que são: a ilusão dos sentidos, o argumento dos sonhos e o gênio maligno, o autor elaborou uma conexão entre o pensamento do sujeito e a realidade objetiva, em sua busca pela verdade inquestionável através do método, utilizando os critérios de clareza e distinção (DESCARTES, 2001).

Outro filósofo que trabalha o conceito de verdade é Heidegger, em sua obra retoma o termo da aletheia que significa "o que não está oculto", trata-se de um desvelamento, de uma manifestação daquilo que outrora não estava ao alcance das vistas. Para o autor, é possível diferenciar dois aspectos de verdade: o primeiro é concebido pela via tradicional, significa dizer que teve uma utilização corrente na metafísica ocidental. Através do termo em latim Veritas est adaequatio rei et intellectus a verdade é relacionada à realidade, portanto há uma adequação ao que existe, a transliteralidade da expressão significa que a verdade é a adequação da coisa ao intelecto.

Nessa concepção de verdade existe uma linearidade de pensamento. Heidegger constrói o seu conceito de verdade a partir de uma crítica à metafísica utilizando o termo aletheia com a finalidade de compreender que o desvelamento do ser está ligado a um exercício de liberdade, assim, o conceito de verdade sofre uma modificação metafísica. O que não deve ser esquecido, o que não deve ser escondido e o que não deve ser velado é a verdade que deve estar em movimento no sentido de vir-a-ser ao ser-do-ente. 
Outra consideração tecida por Heidegger em sua obra sobre "A essência da verdade" gira em tornar da ideia de que a verdade está essencialmente conectada a uma recusa do ser a uma apreensão definitiva, significa dizer que a verdade se movimento da forma contínua sem se fixar definitivamente, se abrindo para os acontecimentos, o que Heidegger vai chamar de história como errância. A compreensão do Dasein como ente que se lança no mundo, portanto pode ressignificar os seus projetos, não pode estar pautada em uma verdade que seja definitiva.

Após o percurso de estudo histórico da verdade em epígrafe se apresenta importante compreendermos o momento atual, nesse sentido é possível afirmar que no campo da informação, especialmente com avanço da internet e das redes sociais, a concepção de verdade adquire uma nova significação. Para melhor compreensão, deve-se perceber que a informação propagada virtualmente nem sempre está atrelada a uma realidade factual.

Entretanto, estabelecer critérios que se relacionem com a distinção entre informação verdadeira de informação falsa vem se configurando como uma necessidade para o acesso à informação enquanto um direito constitucional. Insta esclarecer que informação não é conhecimento, contudo está na produção deste, informação é um conjunto de dados reproduzidos enquanto o conhecimento é resultado de um processo de reflexão e aprendizagem crítica.

A informação aqui trabalhada diz respeito aos dados que são publicados em meio social, cabe destacar que com o desenvolvimento das tecnologias e a conexão ilimitada apontou uma preocupação a origem e a verdade da informação propagada, nesse sentido busca-se que haja um compromisso com a informação que deva ser considerada verdadeira, em termos contemporâneas significa dizer que a informação tem que ter adequação com a ciência e ser, portanto, uma informação oriunda de estudos, pesquisa, especializações.

A importância da veracidade de informação se dá pela modificação que acontece em meio social por causa da Era Digital, a modernidade líquida é fruto de uma revolução tecnológica que transformou completamente as atividades humanas, portanto, em dias atuais busca-se não disseminar informações que não possuem adequação com realidade, o não compromisso com a realidade dos fatos transformam a vida em sociedade em um espaço caótico, o que resta claro se opõe à necessidade de organização social. O meio digital pode trazer consequências sérias ao meio social físico. Philbeck (2017) versa que:

O acesso digital, segundo a UNESCO, está centrado na vida das cidades. Considerase necessário delimitar os conteúdos informacionais presentes tanto no campo 
científico custodiado nos acervos, quanto aqueles conteúdos ditos informacionais presentes nas comunidades, que têm o acesso com velocidade acelerada pelas redes sociais e são disseminados enquanto informação.

Percebe-se a preocupação da Organização das Nações Unidas para a Educação, a Ciência e a Cultura com acesso digital e com a qualidade dos conteúdos das informações. Importa ainda dizer que com alinhamento ao compromisso da verdade das publicações surge e se expande a Ciência da Informação, que apresenta uma lógica de realidade a ser conectada com as informações prestadas.

Ainda no ideário de preocupação com a vinculação de informações, em maio de 2021 a Unesco, publicou uma nova Meta que tem como objetivo melhorar proteção de direitos humanos; alternativa ficaria entre extremos de regulamentação excessiva e abordagem liberal; publicação faz parte da série Tendências Mundiais em Liberdade de Expressão e Desenvolvimento da Mídia, com essa Meta a Unesco busca aumentar a transparência ao produzir conteúdo publicados o intuito é mediar uma ideia que permeia a regulamentação excessiva de conteúdo, que limita à liberdade da pessoa, e uma abordagem liberal gerando conteúdos problemáticos, que incentiva o discurso de ódio e a desinformação (UNESCO, 2021).

Ainda perseguindo um olhar filosófico a respeito da concepção da verdade, tem-se o filósofo Charles Peirce e seu método científico pautado pelo uso da lógica como instrumento que viabiliza à filosofia que se alcance um conjunto de significações verdadeiras. A metodologia de Peirce ecoa como um caminho para se atingir aquilo que mais se aproxime da verdade por meio das relações dos signos e que possa ser reconhecível e alcançável. Assim, a verdade é alcançada através do encadeamento lógico e considerada por dedução. Entende-se por signo em Peirce aquilo que se situa entre o objeto e o efeito que o mesmo provoca (MORAES, ALMEIDA, \& ALVES, 2020).

[...] O resultado final do pensamento é o exercício de volição, e não faz parte mais deste pensamento; mas a crença é apenas um estágio da ação mental, um efeito sobre nossa natureza adequada ao pensamento, que influenciará o pensamento futuro. (PIERCE apud MORAES, ALMEIDA e ALVES, 2020, p. 255)

A citação supra representa o chamado Pragmaticismo que é um instituto que busca compreender as manifestações pelo critério de verdade que conecta o signo e seu agente interpretador, significa dizer que a verdade se encontra em espaço significante da dedução, 
portanto, encadeado por uma lógica ${ }^{5}$. Disso resulta que haja a criação de um hábito que permita que nosso comportamento não precise ser constantemente implicado no método dedutivo para atingirmos a verdade, pois já “a crença e a maneira de ação, vão se constituir em um hábito, que é a maneira pela qual agimos sem ter que a cada momento deduzimos novos métodos para aquilo que é a atuação no cotidiano" (MORAES, ALMEIDA, \& ALVES, 2020)

Portanto, podemos notar que existe um esforço da filosofia ocidental em explicar a verdade. Acrescenta-se ainda que em tempos de modernidade líquida e eras digitais perfazem a construção de outro momento, que é o da pós-verdade, nesse sentido cabe investigar seu conceito e construção.

Segundo a definição encontrada no Dicionário Oxford, pós-verdade é "um adjetivo definido como 'relatando ou denotando circunstâncias em que fatos objetivos são menos influentes na opinião pública que os apelos emocionais e as crenças pessoais" (OXFORD, 2016). Vemos que o conceito de pós-verdade é fruto de uma série de acontecimentos localizados na contemporaneidade e está relacionado com uma construção linguística que acabou por criar uma nova expressão, reformulando o sentido da palavra verdade, trata-se de um fenômeno espontâneo da sociedade que teve como origem as novas relações sociais oriundas das eras digitais.

O termo cunhado em inglês "post-truth" figura em uma célebre frase atribuída primeiramente a Steve Tesich em 1992 "we live in a post-truth era", e que foi retomada em 2004 por Ralph Keyes. Ganha popularidade com dois eventos em particular, o Brexit e durante a campanha de Donald Trump à presidência. A partir desses acontecimentos a pósverdade passa a fazer parte do vocabulário discursivo na política.

O ponto de destaque está em observar um deslocamento valorativo da verdade. A modulação da opinião pública se perfaz por um apelo emocional que é desconectado dos fatos objetivos da política. Pode-se dizer que há um esforço para deslocar os fatos para um segundo plano em um cenário político. A pós-verdade se situa em uma disputa imagética da aparência,

\footnotetext{
${ }^{5}$ Moraes (2020) ensina que "a significação vai ao encontro da expectativa de um resultado que podemos deduzir, numa inferência que torna real a possibilidade para qual se encaminha o raciocínio. O signo se interpõe entre o objeto que representa e o efeito que pode causar em uma mente interpretante, seja para confirmar o hábito ou abrir novas possibilidades de significação".
} 
ou seja, "algo que aparente ser verdade é mais importante que a própria verdade" (FIGUEROA, 2016).

Rouco (2016) e Rojas (2016) compreendem que a pós-verdade é apenas uma forma eufemística de falar sobre mentira e fraude, e esse método faz parte da retórica política. Resta claro que o compromisso com a verdade não é uma opção, pois o que se apresenta é uma disputa de perspectiva, portanto, "posverdad no es más que un encubrimiento políticamente correcto de lo que ha pasado: se ha mentido, se ha estafado" (ORTEGA apud ROUCO, 2016, p. 13).

A pós-verdade apresenta sua manifestação nos espaços sociais a partir do ano 2000, contudo, é em 2016 que é eleita como palavra do ano pelo Dicionário de Oxford. Pós-verdade é tradução da expressão inglesa "Post-Truth", resta claro que sua relevância perdura até os dias atuais. A sua configuração se dá em uma autoridade midiática, o estatuto de credibilidade não está mais no argumento científico, assim, a pós-verdade se insere em uma autoridade da repetição na qual o critério de validade está na tendência de um hábito que é da ordem da conveniência (MORAES, ALMEIDA, \& ALVES, 2020, p. 11).

Outra importante consideração é a concepção da pós-verdade como relativismo epistêmico que representa uma verdade variável conforme o contexto, Higgins (2016) acredita que existem tipos distintos de relativismo em que se situam um extremo e um racional, o primeiro não permite um diálogo entre as partes uma vez que a verdade é pessoal e está calcada na subjetividade de cada um, tal qual um juízo gustativo, a segunda considera uma base mínima sobre o que verdade.

A perspectiva nietzschiana, expressa no seguinte excerto "não há fatos, apenas interpretações" (NIETZSCHE, 1998, p. 31) diz respeito a uma crítica do absolutismo da verdade defendida pelos platônicos. A utilização atual da expressão filosófica relacionada à pós-verdade possui uma significação da indiferença, o que claramente não é uma sugestão do pensador. Ainda que Nietzsche critique a verdade absoluta, ele não trabalha com uma estratégia de desvalorização da verdade em que os fatos não são levados em consideração, mas sim as conveniências pessoais. 
É possível observar que a pós-verdade é utilizada nos tempos pós-modernos ${ }^{6}$ como uma verdade que é característica desse período. A proposta do pensamento pós-moderno do Lyotard (1986) traça uma crítica que compara a possibilidade de libertação da sociedade da ignorância e da miséria atravessados pela guerra e pela tirania das mídias, o que é claramente uma violação do indivíduo. $\mathrm{O}$ autor em epígrafe dá ênfase à condição do dissenso e propõe uma reformulação pelo viés estético.

Após a compreensão que o pós-moderno não possui uma fundamentação definitiva, portanto o discurso não transcende aos valores e virtudes, Lyotard (1986) compreende como solução a via do reconhecimento da diferença e da pluralidade. Esse autor nos apresenta um esforço que Feitosa (2017) chama de antidogmático. O consequente pensamento que se tem é que a pós-verdade seriam uma mentira no campo de atuação da política, portanto numa esfera pública que estaria ligado diretamente a uma manipulação dos cidadãos.

Já para Dunker (2017) considera que há um embaralhamento proposital de elementos verdadeiros e falsos que confundem a ponto de não deixar evidente que se trata de uma mentira e, assim, ganhar ares de semelhança, ou em última instância, de verdade, como podese ler em:

[...] alguns consideram que o discurso da pós-verdade corresponde a uma suspensão completa de referência a fatos e verificações objetivas, substituídas por opiniões tornadas verossímeis apenas à base de repetições, sem confirmação de fontes. Penso que o fenômeno é mais complexo que isso, pois ele envolve uma combinação calculada de observações corretas, interpretações plausíveis e fontes confiáveis em uma mistura que é, no conjunto, absolutamente falsa e interesseira. (DUNKER, et al., 2017, p. 38)

Nessa toada, a relação entre verdade e política também foi abordada por Hanna Arendt. A referida filósofa trabalhou com uma perspectiva imaginária em relação a gestão do político ao apresentar a possibilidade da utilização da mentira no discurso político, denominou como "lugar comum" a significação inerente de verdade e política de verdade e política não serem compatíveis. Resta claro que a sua concepção tinha um viés de crítica à tirania, que por sua vez pregavam verdades absolutas e instauram práticas totalitárias.

Vale salientar que para a autora a verdade possui uma essência política, portanto é circunstancial. Essa tese possibilita uma abertura para a utilização de mentiras na esfera pública. A mentira agora é utilizada como um instrumento político e está diretamente

\footnotetext{
${ }^{6}$ Cabe esclarecer que pós-modernidade não é um conceito claro e acaba representando uma estrutura sociocultural desde os anos 1980. Para nós a pós-modernidade é fundamentada na filosofia de Bauman e nosso interesse é compreender as características de uma sociedade globalizada e altamente conectada.
} 
relacionada ao exercício de poder. Essa gestão estratégica da mentira se operacionaliza pelos meios de comunicação que na época de Arendt eram utilizados pelos regimes totalitários.

Sua construção filosófica nos apresenta um alargamento da concepção de verdade que quando utilizada como um instrumento de manipulação se perdeu o viés essencial da verdade enquanto orientação moral. O reconhecimento da mentira como estratégia levou à descrença de uma verdade enquanto autoridade (ARENDT, Verdade e Política, 1967).

Portanto, em uma sociedade contemporânea o ser enganado não é julgado com rigidez pois está imersa de forma sistêmica a possibilidade que isso ocorra, tanto nos discursos políticos como na reprodução das redes sociais a informação não necessariamente verdadeira não é um problema, haja vista esse espaço de fluidez em que tudo é possível por muitas vezes possui um contato de um não processo pensante, portanto, não crítico. Arendt nos apresenta a descrença generalizada da realidade (FEITOSA, 2017).

Segundo Genesini (2018), encarar que vivemos em um mundo pós-verdadeiro supõe que antes havia um mundo em que a verdade objetiva era o paradigma praticado pela maioria. Na concepção do autor esse mundo nunca existiu e, portanto, nunca retornará, pois "superar" a pós-verdade não consiste em voltar a um cenário de supremacia da verdade enquanto categoria distintiva. Genesini (2018) faz coro àqueles que consideram que a verdade pertence a um rol de subjetividades em disputa.

Entretanto, ao recuperar a noção de verdade factual, Genesini (2018) aciona o comportamento expresso por Arendt como função da mídia de checagem e apuração dos fatos para que estes não fossem cooptados pelos interesses políticos vigentes. Este modo de atuação de uma parcela política está novamente sendo posta em prática com a apropriação de fatos em favor de um discurso que os beneficie. Dessa maneira,

Não há nenhuma novidade na tentativa de falsificação política através da distorção de fatos e informações. O novo é que estamos em uma nova era, turbinada pela internet e pelas redes sociais, em que o crescimento é viral e o efeito, exponencialmente explosivo. (GENESINI, 2018, p. 49)

O falseamento da realidade, então, não é um fenômeno recente, mas algo que permeia a história de um modo geral. O fator de destaque do nosso tempo é o meio pelo qual esse falseamento se opera. As três grandes plataformas elencadas pelo autor são o Facebook, o Google e o Twitter como o grande diferencial da atualidade que esbarram na possibilidade de manutenção ou consolidação do viés democrático (GENESINI, 2018). 
O uso dessas redes aliado a disseminação de fake news apresentou seu impacto na política mundial nos últimos anos, mais especificamente na campanha do ex-presidente estadunidense Donald Trump. Abordaremos de modo mais detalhado sobre essa temática em tópico posterior destinado às eleições, entretanto, vale mencionar a maneira de criar versões alternativas da realidade promovidas por Trump.

Em sua conta pessoal no Twitter, Trump passou a atacar notícias e veículos que iam contra sua construção narrativa e que os desfavorece de certo modo, acusando-os de propagar fake news. Esta atuação culminou na "premiação" das fake news tendo como vencedores veículos de imprensa como o New York Times e o Washington Post. Surgiram assim extensas evidências de interferência nas eleições estadunidenses com envolvimento dos russos em que o Facebook aparece no centro dos acontecimentos, pois os posts alcançaram metade da população, evidenciando o impacto que provocaram (GENESINI, 2018).

Após cobranças para que medidas fossem tomadas, o Facebook anunciou que passaria a combater o avanço da propagação de notícias falsas na plataforma através da contratação de cerca de 20 mil profissionais. Esse fato chama a atenção pelo alto número de pessoas envolvidas na ação, mas Genesini (2018) aponta que a complexidade da questão está intimamente ligada à dificuldade com a identificação de fake news.

No centro da discussão está a constatação de que identificar fake news ou
mensagens de ódio não é fácil. Se fosse fácil e programável, um robô resolveria o
problema, ou pelo menos boa parte dele. Nem mesmo com todo o avanço da
inteligência artificial Mark parece confiante que o serviço possa ser feito sem ajuda
humana. (GENESINI, 2018, p. 50)

Outra expressão que surge nesse ínterim é o fact checking que significa a checagem dos fatos é uma metodologia de comprovação das informações, uma forma de possibilitar a circulação de qualidade de fatos e informações. Cabe destacar que este recurso possibilita o que os jornalistas vão chamar de grau de verdade das informações, trata-se de uma verificação entre fatos e realidade. Gregório Duvivier em uma alusão a uma passagem da bíblia sobre a libertação pela verdade utiliza a metáfora "Conhecereis a checagem e a checagem vos libertará”, com intuito de contribuir com a ideia de que as informações que são comprovadas fazem diferença no atual cenário (DUVIVIER apud SILVA, 2019).

O confronto entre o discurso e a realidade possibilita a deturpação de informação para angariação de votos, ou discursos convenientes que se afastam com as atividades necessárias para um ambiente político democrático. A questão que surge é que as redes sociais como 
exemplo temos Whatsapp que até 2021 não possui uma regulamentação sobre o conteúdo compartilhado.

As formas possíveis de manipulação são muitas, frases com efeito, informações pela metade, títulos sensacionalistas, para Flores (2017) há uma conexão entre fake news e pós verdade que são catalisados por insinuações, portanto, por inferência as pessoas são levadas a determinadas interpretações. Vê-se em:

Em um contexto comunicativo cujo conteúdo proposicional possa ser considerado
válido, diz-se que o indivíduo comunicador enuncia. Já em um contexto
comunicativo cujo conteúdo proposicional apenas pretenda ser considerado válido,
diz-se que o indivíduo comunicador insinua. A insinuação se ancora
fundamentalmente no princípio de desencadear inferências de natureza falseadora,
pelo apelo consciente a crenças ou a impressões arraigadas ao interlocutor
(FLORES, 2017, p.22).
Nesse processo de insinuação, a proposta do conteúdo veiculado não é apresentar
fatos. Nele, os fatos passam a ter importância secundária; em alguns casos, "os fatos
podem simplesmente não ter importância e passam a ser ignorados face às
interpretações parciais". (FLORES, 2017, p. 26)

Destarte, a insinuação é uma ferramenta da pós-verdade por distanciar a valorização da verdade, não importa a veracidade dos fatos, o que ocorre é que os próprios fatos não ficam em um segundo plano de importância. O que fica em primeiro plano é a interpretação parcial, superficial, imediata. A pós-verdade alimenta um projeto político de diminuição da percepção do seu interlocutor no conteúdo que aprofunde e se atenha aos fatos.

Como visto em epígrafe há um desequilíbrio em relação a emoções e racionalidade quando se trata do que prepondera na informação da pós-verdade, nesse sentido as informações sensacionalistas ganham espaço, o fluxo de troca de informação na atualidade é intensificado, há uma atração do ser humano as informações sensacionalistas por essa afetar diretamente as emoções

Portanto, a irresistível atração que o sensacionalismo exerce sobre as emoções humanas está longe de ser uma invenção da internet, embora esta tenha levado isso ao extremo, com a adição agora da dificuldade de se diferenciar o trágico factual do trágico fantasiado (SANTAELLA, 2018, p. 32).

Demonstrada a dificuldade em conceituar a pós-verdade cabe analisar o percalço em regulamentar essa temática no país. Macedo (2020) identifica um posicionamento não liberal em relação à liberdade de expressão. Nesse sentido, é possível encontrar projetos de leis que possuam uma postura restritiva, por vezes violando o direito de liberdade de expressão assegurados pela CRFB/88. 
A título de ilustração, o autor em epígrafe apresenta a ADPF 130-7/DF que reafirma os princípios de liberdade de expressão que são valores constitucionais, trata-se da Lei 5250/67 que destaca uma violação à Constituição quando criminaliza enquanto ofensa criminal a publicação de notícias falsas.

Em contraponto, em 2018 o TSE performou um posicionamento mais repressivo quando determinou a exclusão de informações não verdadeiras sobre a candidata à presidência Marina Silva. Foi uma ação da Rede De Sustentabilidade em combate de fake news, apresentando inclusive os links contendo as notícias.

Atualmente muito se discute a respeito de um tipo de veiculação de notícias que estariam na contramão do propósito informativo voltado para a ampliação de conhecimento sobre um dado assunto, as notícias falsas. Compreendendo-se que as fakes news seriam um então avessas ao caráter informativo, Shu et al (2017) salientam que existem duas características principais para delimitar o conceito de fake news: descompromisso com a autenticidade e o intuito de enganar o leitor.

Desse modo, Recuero e Gruzd (2019) destacam que entre fake news e sátiras há diferenças tanto de propósito quanto de formato. As sátiras já apresentam sua intencionalidade a partir do formato discursivo utilizado carregado de humor, tornando evidente que não têm a pretensão de soar autêntico ou de enganar aquele que lê. Já as fakes news são divulgadas com a intenção de provocar desinformação, mas utilizando-se de um formato discursivo aproximado das notícias reais.

Por se apropriar de um formato utilizado no jornalismo, as fakes news têm o propósito de gerar nos leitores a crença necessária para que sua difusão propague e atinja mais leitores e que aparenta tratar-se de notícia verdadeira. Recuero e Gruzd (2019, p. 32) apontam que a intenção de enganar é um ponto crucial para caracterizar as fake news, pois não se restringe a "uma informação pela metade ou mal apurada, mas de uma informação falsa intencionalmente divulgada, para atingir interesses de indivíduos ou grupos."

De acordo com Himma-Kadadas (2017), outra característica presente nas fake news é seu aspecto noticioso que possibilita provocar credibilidade, pois confunde o leitor com uma notícia jornalística séria. Na visão de Recuero e Gruzd (2019), esse tom jornalístico é um componente importante na adesão das fake news, justamente por se utilizarem de um modelo narrativo semelhante ao praticado no jornalismo que confere legitimidade. Nesse sentido, aos 
autores acreditam que para definir o que são as fakes news é importante considerar três aspectos:

1) o componente de uso da narrativa jornalística e dos componentes noticiosos; (2) o componente da falsidade total ou parcial da narrativa e; (3) a intencionalidade de enganar ou criar falsas percepções através da propagação dessas informações na mídia social. (RECUERO; GRUZD, 2019, p. 33)

O que resulta dessa combinação é a desinformação das pessoas que acreditam naquela notícia veiculada. Atualmente o maior campo de propagação de fake news é no ambiente online. A internet tem despontado há muitos anos como um componente intrincado na vida cotidiana de milhões de pessoas ao redor do mundo e funcionando como lugar fértil da proliferação de notícias falsas com os mais diferentes propósitos.

Outro conceito importante que auxilia no entendimento da difusão das fake news é apontado por Recuero e Gruzd (2019) como cascata de informações que seria uma reprodução em sequência de conteúdo anteriormente partilhados por outras pessoas o que de alguma forma os torna validados, isto é, trata-se da repetição de um dado comportamento praticado anteriormente por outras pessoas sem que se faça uma análise crítica.

Na cascata de informações há o compartilhamento de notícias sem a devida checagem ou verificação, pois se está repetindo a ação de veicular informações porque outras pessoas assim o fizeram antes. "Assim, uma cascata é qualificada pela reprodução de informações baseadas na compreensão do comportamento dos atores anteriores como verdadeiro pelos posteriores, mesmo que estes não tenham como saber.” (RECUERO; GRUZD, 2019, p. 34).

Nessa toada, os autores salientam também que estar em contato com pessoas semelhantes amplia o efeito cascata de informações, pois há certa identificação. Essa característica se chama homofilia e é precisamente esse vínculo que ocorre devido às similaridades que facilita que as notícias sejam compartilhadas mais facilmente por mais pessoas (RECUERO; GRUZD, 2019).

Essa tendência é observável na esfera política quando grupos com ideologias comuns têm amplamente disseminado em seu meio notícias com um teor que congrega os valores por eles estimados promovendo de maneira muitas vezes involuntária a formação de nichos fechados em si, as chamadas bolhas (RECUERO; GRUZD, 2019). A identificação ideológica contribui para a difusão de fake news entre grupos de direita no Brasil, inclusive com organização voltada para a finalidade de enganar deliberadamente. 
Nesse sentido, as fakes news propagadas através das cascatas de informação tendem a circular com mais facilidade dentro de grupos em que há homofilia, ou seja, grupos que partilham de orientação ideológica semelhante e que tenham valores comuns. Isso ganha mais espaço na medida em que se entende que o comportamento individual ecoa padrões estabelecidos e até mesmo induzidos através dos mecanismos tecnológicos que monitoram nossa ação na internet, conforme já discutido anteriormente. A partir disso, Genesini (2018) corrobora a ideia de que a tecnologia tem influenciado a propagação das informações, sendo verdadeiras ou falsas.

O que, atualmente, é radicalmente diferente é o poder e a influência das plataformas
de tecnologia na disseminação de qualquer tipo de notícia que, por razões variadas e
muitas vezes inexplicáveis, ganham engajamento e, de uma hora para outra, crescem
exponencialmente sua audiência. São gostadas ou detestadas (likes e similares),
compartilhadas e comentadas em um processo de combustão espontânea
descontrolada. (GENESINI, 2018, p. 54)

Desses processos de difusão de notícias surge a questão de como controlar, combater ou mesmo exterminar o avanço da propagação de fake news em ambiente virtual. Essa discussão não se restringe ao Brasil, pelo contrário, ao redor do mundo muitos países têm discutido medidas para conter a disseminação das fake news. Muitas das medidas apontadas têm sido alvo de críticas por serem consideradas controversas no que diz respeito à salvaguarda da liberdade de imprensa e da não censura. Talvez uma medida importante seja a responsabilidade recair sobre as plataformas.

Entretanto, Genesini (2018) aponta que o Facebook, que é a plataforma em que as fakes news mais foram propagadas, ultrapassando o Google e o Twitter, assumiu a responsabilidade sobre o impacto que a plataforma teve nas eleições americanas de 2016 e resolveu adotar mudanças no algoritmo. O imbróglio que se apresenta é que os algoritmos do Facebook são programados para aumentar o tempo de exposição do usuário na plataforma e, dessa maneira, aumentar as chances de conhecer o usuário e poder vender a ele produtos com base na sua atuação online (GENESINI, 2018).

Esse caso americano evidenciou como as fakes news podem atuar para influenciar o resultado das urnas no processo eleitoral. As redes sociais se revelaram campo propício para a difusão de informações falsas em larga escala devido a sua agilidade de comunicação entre os indivíduos. Segundo Recuero e Gruzd (2019), elencam dois importantes fatores para o "sucesso" da propagação dessas notícias: algoritmos e gostos pessoais. 


\section{CONCLUSÃO}

Se por um lado as informações alcançam os indivíduos a partir da tecnologia empregada trabalhar para atingir os usuários com base na sua atividade virtual, como é o caso dos algoritmos, por outro tem-se a divisão extremada de grupos opostos nas redes ocupando os polos do espectro político, isto é, o compartilhamento de dada notícia será com base nas escolhas individuais guiadas por um conjunto de valores que se alinhem a alguma ideologia.

Disso decorre que haja a chamada polarização, uma vez que os usuários estão mais abertos àquelas notícias que, de alguma forma, corroboram o modo como eles mesmos entendem a realidade, provocando então uma divisão marcada de lados diferentes no debate político.

Tal característica presente no modo organizacional de difusão de informações das redes sociais funciona como um agente facilitador para a propagação de fake news, uma vez que o disparo de tais notícias encontra solo fértil dentro das bolhas criadas. Nesse sentido, as fake news de cunho político eleitoral se destacam como um tipo que alcança espaços e têm grande adesão em determinados grupos com narrativas mais conservadoras, preconceituosas, pois geram aproximação de valores comuns (RECUERO; GRUZD, 2019).

$\mathrm{O}$ atual artigo buscou compreender como objetivo geral a investigação de verdade, pós-verdade, seu conceito e história com a finalidade de fundamentar estudo sobre a influência do fenômeno das fakenews que acontece das redes sociais, sendo este o objetivo específico. Perscrutou os filósofos clássicos como Platão, Sofistas, Heidegger compreendendo o conceito em si.

Destarte, a construção da verdade e da pós-verdade. Restou claro que a pós verdade, este relativismo epistemológico, não pode ser concebido como algo que não possui repercussão no mundo social, e está diretamente inserida em uma realidade de transformações aceleradas e que o porte jurídico regulatório nacional, ora apresenta um viés liberal em relação às liberdades de expressão, ora apresenta um viés repressivo.

Investigou ainda a pós-verdade enquanto um conceito contemporâneo em termos históricos e suscita um entendimento de uma verdade, que é um conceito que atravessa toda a história da filosofia. Através da metodologia de pesquisa exploratória pelo método de 
levantamento de bibliográfico, conseguiu se compreender como resultados esperados que a fakenews se trata de um falseamento da realidade que incorre em manipulação da sociedade.

\section{BIBLIOGRAFIA}

ABBOUD, Georges; NERY JR, Nelson; CAMPOS, Ricardo Resende. Fake news e regulação. Revista dos Tribunais; Nova Edição, 2020.

ALEXY, R. (2017). Teoria dos Direitos Fundamentais. São Paulo: Printed in Brasil.

ARENDT, H. (fevereiro de 1967). Verdade e Política. The New Yorker.

ARENDT, H. (2011). Sobre a Revolução. Tradução: Denise Bottmann. São Paulo: Companhia das Letras.

ARISTÓTELES. (1997). Política (3 ${ }^{\mathrm{a}}$ ed.). Brasília: UnB.

ARISTÓTELES. (2001). Ética a Nicômaco (4ª ed.). Brasília: UnB.

BARROS, A. R. (2001). A Teoria de Soberania de Jean Bodin. São Paulo: Unimarco. 
BAUMAN, Z. (1999). Globalização: as consequências humanas. Rio de Janeiro: Zahar.

BAUMAN, Z. (2001). Modernidade Líquida (1ª ed.). Rio de Janeiro: Zahar.

BAUMAN, Z. (2013). A cultura no mundo líquido moderno. Rio de Janeiro: Zahar.

BOBBIO, N. (1987). Estado, governo e sociedade. Para uma teoria geral da política. Rio de Janeiro: Paz e Terra.

BOBBIO, N. (2009). O Futuro da democracia (15 ed.). Rio de Janeiro: Paz e Terra.

CADWALLADR, C. (2018). Data war whistleblower Christopher wylie faceook nix bannon Trump. Acesso em 03 de julho de 2021, disponível em The Guardian: https://www.theguardian.com/news/2018/mar/17/data-war-whistleblower-christopherwylie-faceook-nix-bannon-trump

CARVAlHO, J. M. (2020). Cidadania no Brasil: O longo caminho (26 ${ }^{\mathrm{a}}$ ed.). Rio de Janeiro: Civilização Brasileira.

D'ANCONA, M. (2018). Pós-verdade: a nova guerra contra os fatos em tempos de fake news. Barueri: Faro Editorial.

DERRIDA, J. (2005). A Farmácia de Platão. São Paulo: Iluminuras.

DERRIDA, J., \& ROUDINESCO, E. (2004). De que amanhã...: Diálogos. Rio de Janeiro: Zahar.

DIAS, R. C. (2009). Relações de poder na Alta Idade Média e suas ressonâncias no defensor pacis de Marsílio de Pádua: análise comparativa de documentos de épocas distintas. In: VIII Jornada de Estudos Antigos e Medievais e I Jornada Internacional de Estudos Antigos e Medievais (pp. 54-54). Maringá: Caderno de Resumos da Jornada de Estudos Antigos e Medievais.

DINIZ, E. (1995). Governabilidade, democracia e reforma do Estado: os desafios da construção de uma nova ordem no Brasil dos anos 90. Revista de Ciências Sociais, $38(3), 385-415$.

FEITOSA, C. (2017). Pós-verdade e política. Acesso em 12 de junho de 2021, disponível em Revista Cult: https://revistacult.uol.com.br/home/pos-verdade-e-politica/

FERRAJOLI, L. (2002). A Soberania no Mundo Moderno: nascimento e crise do estado nacional. São Paulo: Martins Fontes.

FIGUEROA, G. C. (2016). Post-verdad, nueva forma de la mentira. Acesso em 30 de junho de 2021, disponível em Le Clarin: https://www.clarin.com/opinion/Post-verdadnueva-forma-mentira_0_HyjwGEMMg.html 
FLORES, P. J. (2017). Inferências Falseadoras Como Base Para A Pós-Verdade. Língua e Letras, 18(41), 20-32.

FOUCAULT, M. (1999). Em defesa da sociedade: curso no Collège de France (1975-1976). São Paulo: Martins Fontes.

FOUCAULT, M. (2014). Vigiar e Punir: Nascimento da prisão. Petrópolis: Vozes.

FRIEDE, R. (2000). Curso de Teoria Geral do Estado: Teoria Constitucional e Relações Internacionais. Rio de Janeiro: Forense Universitária.

GOMES, N. L. (2018). Uma análise acerca do fenômeno das fake news no processo eleitoral e suas interfaces com o direito fundamental à liberdade de expressão. Monografia (Graduação) - Centro de Ciências Jurídicas - Universidade Federal da Paraíba, João Pessoa.

HAN, B.-C. (2018). No exame: Perspectivas do digital. Petrópolis: Vozes.

HARDT, M., \& NEGRI, A. (2001). Império. Rio de Janeiro: Record.

HARDT, M., \& NEGRI, A. (2005). Multidão: guerra e democracia na era do império. Rio de Janeiro: Record.

HEIDEGGER, M. (1993). Ser e Tempo. Petrópolis: Vozes.

HEIDEGGER, M. (2008). Marcas do Caminho . Petrópolis: Vozes.

HEIDEGGER, M. (2008). Parmênides. Petrópolis: Vozes.

HESPANHA, A. M. (2005). Cultura jurídica europeia: síntese de um milênio. Florianópolis: Fundação Boiteux.

JONES, R. C. (2016). Como o Facebook pode ter ajudado Trump a ganhar a eleição. Acesso em 30 de junho de 2021, disponível em BBC News: https://www.bbc.com/portuguese/geral-37961917

KOHN, K., \& MORAES, C. H. (2007). O impacto das novas tecnologias na sociedade: conceitos e características da Sociedade da Informação e da Sociedade Digital. XXX Congresso Brasileiro de Ciências da Comunicação (pp. 12-24). Santos: Anais.

LEMOS, A. (2002). Cibercultura: tecnologia e vida social na cultura contemporânea ( $7^{\mathrm{a}}$ ed.). Porto Alegre: Sulina.

LEONARDI, M. (2009). Tutela da privacidade na Internet. Tese (Doutorado) - Faculdade de Direito - Universidade de São Paulo, São Paulo.

LÉVY, P. (2010). Cibercultura (3ª ed.). São Paulo: Editora 34. 
LOBÃO, B. d. (2020). Modernidade líquida: uma análise das relações líquidas à luz dos conceitos de zygmunt bauman. III Mostra de ensino, pesquisa e extensão da FACAPE. Petrolina: Caderno de resumos.

LOPES, D. R. (2017). Protágoras, de Platão. São Paulo: Perspectiva.

LYOTARD, J.-F. (1986). A condição pós-moderna (13 ${ }^{\mathrm{a}}$ ed.). Rio de Janeiro: José Olympio.

MARCONDES, D. (1997). Iniciação à história da filosofia: Dos pré-socráticos a Wittgenstein ( $2^{\mathrm{a}}$ ed.). Rio de Janeiro: Zahar.

MORAES, S., ALMEIDA, C., \& ALVES, M. (2020). Informação, verdade e pós-verdade: uma crítica pragmaticista na ciência da informação. Encontros Bibli, 25, 01-22.

NEGROPONTE, N. (1995). Vida digital. São Paulo: Companhia das Letras.

NIETZSCHE, F. (1998). Genealogia da moral: uma polêmica. São Paulo: Companhia das Letras.

PELBART, P. P. (2003). Vida Capital. São Paulo: Iluminuras.

PEREIRA, A. C. (janeiro de 2002). A Soberania no Estado Pós-Moderno. Revista de Ciências Jurídicas da Universidade Veiga de Almeida, 1(1), 23-61.

PEREIRA, L. C., WILHEIM, J., \& SOLA, L. (1999). Sociedade e Estado em transformação. Brasília: Enap.

QUEIROL, R. d. (2016). Zygmunt Bauman: “As redes sociais são uma armadilha”. Acesso em 10 de abril de 2021, disponível em El País: https://brasil.elpais.com/brasil/2015/12/30/cultura/1451504427_675885.html

RAIS, Diogo. Fake News: a conexão entre a desinformação e o direito. São Paulo: Revista dos Tribunais, 2020.

RECUERO, R. (2009). Redes sociais na internet. Porto Alegre: Sulina.

ROUCO, F. (2016). La posverdad se hace viral. Acesso em 30 de junho de 2021, disponível em Bez Diário: https://www.bez.es/306816162/posverdad-viral.html

SILVA, F. d. (2019). O regime de verdade das redes sociais on-line: pós-verdade e desinformação nas eleições presidenciais de 2018. Dissertação (Mestrado) - Programa de Pós-Graduação em Ciência da Informação - IBICT/UFRJ, Rio de Janeiro.

VIANNA, O. (1949). Instituições políticas brasileiras. São Paulo: José Olympio.

VIEIRA, T. M. (2007). O direito à privacidade na sociedade da informação: efetividade desse direito fundamental diante dos avanços da tecnologia da informação . 
Dissertação (Mestrado) - Mestrado em Direito, Estado e Sociedade - Universidade de Brasília, Brasília.

WEBER, M. (2007). A Ética Protestante e o Espírito do Capitalismo. São Paulo: Companhia das Letras. 